\title{
RELATIONSHIP BETWEEN ACIDITY AND CHEMICAL PROPERTIES OF BRAZILIAN SOILS
}

\author{
Cássio Hamilton Abreu Jr. ${ }^{1 *}$; Takashi Muraoka²; André Fernando Lavorante ${ }^{3}$ \\ ${ }^{1}$ USP/CENA - Lab. de Nutrição Mineral de Plantas, C.P. 96 - 13400-970 - Piracicaba, SP - Brasil. \\ ${ }^{2}$ USP/CENA - Lab. de Fertilidade do Solo. \\ ${ }^{3}$ USP/CENA - Lab. Química Analítica. \\ *Corresponding author <cahabreu@cena.usp.br>
}

\begin{abstract}
In soils of tropical climate regions the high acidity and the presence of exchangeable aluminum $\left(\mathrm{Al}^{3+}\right)$, associated to low fertility, are the main restrainting factors for agricultural production. A laboratory experiment was conducted using 26 soils of different Brazilian regions, to investigate soil acidity components, giving emphasis to $\mathrm{Al}$ and their relations with chemical properties. The $\mathrm{pH}$ correlated positively with $\mathrm{P}, \mathrm{Ca}$, $\mathrm{Mg}, \mathrm{K}, \mathrm{BS}, \mathrm{CEC}$ and $\mathrm{V} \%$ values, and negatively with $\mathrm{Al}$ saturation. The $\mathrm{Al}^{3+}$ was the predominant exchangeable cation in $32 \%$ of the soils with $\mathrm{pH}$ below 5.6. The $\mathrm{KCl}$ titratable $\mathrm{H}^{+}$represents the hydroxi- $\mathrm{Al}(\mathrm{OH})_{\mathrm{x}}$ complex with low stability and the Wolf-Morgan extracted Al corresponds to the exchangeable + non-exchangeable $\mathrm{Al}$ species. The $\mathrm{Al}^{3+}$ and low stability hydroxi-Al decreased quickly with increasing $\mathrm{pH}$ up to 5.5. The nonexchangeable $\mathrm{Al}$ increased up to $\mathrm{pH} 4.5$, then decreased to $\mathrm{pH} 5.5$ and had a small increment from 7.0 to 7.5 .
\end{abstract}

Key words: total acidity, exchangeable acidity, $\mathrm{pH}$, aluminum in soil

\section{RELAÇÕES ENTRE ACIDEZ E PROPRIEDADES QUÍMICAS DE SOLOS BRASILEIROS}

\begin{abstract}
RESUMO: Nos solos de regiões de clima tropical, a elevada acidez e a presença de alumínio trocável $\left(\mathrm{Al}^{3+}\right)$, aliadas à baixa fertilidade, são os principais fatores a restringir a produção agrícola. Investigaram-se os componentes da acidez, com ênfase ao alumínio, e suas relações com as propriedades químicas de 26 solos de regiões brasileiras. $\mathrm{O}$ pH correlacionou positivamente com os valores de $\mathrm{P}, \mathrm{Ca}, \mathrm{Mg}, \mathrm{K}, \mathrm{SB}, \mathrm{CTC}$ e V\%, e negativamente com a saturação de $\mathrm{Al}$. $\mathrm{O} \mathrm{Al}{ }^{3+}$ foi o cátion trocável predominante em $32 \%$ dos solos com $\mathrm{pH}$ inferior a 5,6. $\mathrm{O} \mathrm{H}^{+}$titulável em $\mathrm{KCl}$ representa formas hydroxi- $\mathrm{Al}(\mathrm{OH})_{\mathrm{x}}$ de baixa estabilidade e o $\mathrm{Al}$ obtido pelo extrator de Wolf-Morgan corresponde ao Al trocável + não-trocável. As formas $\mathrm{Al}^{3+}$ e hydroxi-Al de baixa estabilidade diminuíram rapidamente com o $\mathrm{pH}$ até 5,5. $\mathrm{O} \mathrm{Al}$ não-trocável aumentou até $\mathrm{pH}$ 4,5, diminuiu a seguir até $\mathrm{pH}$ 5,5 e aumentou lentamente com o pH de 7,0 a 7,5.

Palavras-chave: acidez total, acidez trocável, $\mathrm{pH}$, alumínio no solo
\end{abstract}

\section{INTRODUCTION}

For soils of tropical and humid subtropical climate regions, the high acidity and high exchangeable aluminum content, associated to low fertility, are the main constraints for agricultural production (McLean, 1965; Pavan, 1983; Nachtigall \& Vahl, 1989). Soil acidity is characterized by its intensity and quantity aspects (Kinjo, 1983). The intensity factor is given by the soil solution hydrogen $\left(\mathrm{H}^{+}\right)$ion activity, and the quantity factor, by the amount of $\mathrm{H}$, bound to the exchange complex, which the soil can liberate to solution. There is also the soil acidity capacity factor, which is the resistance to the variation of $\mathrm{pH}$ resulting from the addition of acids or bases, i.e., the soil buffering capacity.

The characterization of soil acidity components is given by the active acidity (intensity factor), usually expressed as soil $\mathrm{pH}\left(-\log \left[\mathrm{H}^{+}\right]\right.$in solution), and by the potential acidity (quantity factor), of which more actual terminology, and hereafter used, is the total acidity (at $\mathrm{pH}$ 7) (Raij et al., 2001). The total acidity, by its turn, is the sum of exchangeable acidity and non-exchangeable acidity. The exchangeable acidity is given by the aluminum ion electrostatically retained by colloid surfaces with $\mathrm{pH}$ dependent negative charges, also called exchangeable aluminum $\left(\mathrm{Al}^{3+}\right)$. The non-exchangeable is related to the content of $\mathrm{H}$ covalently bound to colloids, and monomers and polymers of aluminum in soil (Kinjo, 1983; Thomas \& Hargrove, 1984; Raij et al., 1987; Nachtigall \& Vahl, 1989; Raij et al., 2001).

The detrimental effects of acidity on plant growth depend on the $\mathrm{H}^{+}$and $\mathrm{Al}^{3+}$ ions activities in the soil solution, which may be related to the activities and exchangeable contents of calcium $\left(\mathrm{Ca}^{2+}\right)$, magnesium $\left(\mathrm{Mg}^{2+}\right)$ and potassium $\left(\mathrm{K}^{+}\right)$cations, of orthophosphate $\left(\mathrm{H}_{2} \mathrm{PO}_{4}^{-}\right)$, nitrate $\left(\mathrm{NO}_{3}{ }^{-}\right)$and sulphate $\left(\mathrm{SO}_{4}{ }^{2-}\right)$ anions, and with organic 
matter (MO) content (Pavan, 1983; Thomas \& Hargrove, 1984). With the neutralization of part of the soil total acidity by lime application, negative charges of the soil exchange complex are released, and then occupied by $\mathrm{Ca}^{2+}, \mathrm{Mg}^{2+}$ and $\mathrm{K}^{+}$(Oates \& Kamprath, 1983), improving the soil fertility and the conditions for agricultural production.

The objective of this work was to evaluate the acidity components and their relationship with chemical properties, for improving crop management in soils from different regions of Brazil.

\section{MATERIAL AND METHODS}

The experiment was carried out in Piracicaba (SP), Brazil, using samples collected from the surface layer ( $0-0.2 \mathrm{~m}$ depth) of 26 soils from different Brazilian regions (Table 1). Soil samples with reaction close to neutrality were also included with the objective of evaluating the extraction of non-exchangeable forms of aluminum and to obtain low total acidity values.

Air dried samples of each soil were homogenized, divided in three subsamples, identified, ground in a porcelain crucible and passed through $0.5 \mathrm{~mm}$ mesh sieve and packed. For the chemical characterization of soil samples (Table 2), methods described in Raij et al. (1987; 2001) were used, except for the exchangeable sodium which was extracted with $0.05 \mathrm{~mol} \mathrm{~L}^{-1} \mathrm{HCl}+0.0125$ $\mathrm{mol} \mathrm{L}^{-1} \mathrm{H}_{2} \mathrm{SO}_{4}$ solution in 1:5 (v/v) soil/extractant ratio and determined in flame photometer.

Soil acidity components were characterized as follows: the active acidity was determined in 0.01 mol L ${ }^{-1} \mathrm{CaCl}_{2}$ solution, 1:2.5 (v/v) soil/solution ratio, through $\mathrm{pH}$ measurement; the total acidity $\left(\mathrm{H}+\mathrm{Al}^{3+}\right)$ directly through the extraction with $1 \mathrm{~mol} \mathrm{~L}^{-1}$ ammonium acetate solution at $\mathrm{pH} 7$, followed by titration, and indirectly by SMP method (Raij et al., 1987; 2001). The exchangeable acidity $\left(\mathrm{Al}^{3+}+\mathrm{H}^{+}{ }_{\text {tit }}\right)$ and the exchangeable aluminum $\left(\mathrm{Al}^{3+}\right)$ were extracted by $1 \mathrm{~mol} \mathrm{~L}^{-1} \mathrm{KCl}$ solution, 1:10 (v/v) soil/solution ratio, and determined by titration of $25 \mathrm{~mL} \mathrm{KCl}$ extract with $25 \mathrm{mmol} \mathrm{L}^{-1} \mathrm{NaOH}$, using $1 \mathrm{~g} \mathrm{~L}^{-1}$ phenolphthalein as indicator, and by backtitration, after acidification with $40 \mathrm{~g} \mathrm{~L}^{-1} \mathrm{NaF}$, with $25 \mathrm{mmol} \mathrm{L}^{-1} \mathrm{HCl}$, respectively (routine methodology of Soil Fertility Lab., USP/CENA, adapted from McLean, 1965). The difference between titratable exchangeable acidity and titratable aluminum gave the so-called titratable hydrogen $\left(\mathrm{H}^{+}{ }_{\text {tit }}\right)$ content. The soluble $\mathrm{Al}$ (WM-Al) was extracted with Wolf-Morgan solution $\left(0.73 \mathrm{~mol} \mathrm{~L}^{-1}\right.$ sodium acetate and $0.0001 \mathrm{~mol} \mathrm{~L}^{-1}$ DTPA, $\left.\mathrm{pH} 4.8\right)$ and

Table 1 - Legend, classification, and origin of the soil samples used in the experiment.

\begin{tabular}{|c|c|c|c|}
\hline Legend & Soil classification (Soil Survey, 1999; FAO, 1994; Embrapa, 1999; respectively) & Municipality & State \\
\hline GX & Typic Umbraquult/Dystric Gleisol/Gleissolo Háplico Tb distrófico & Iranduba & AM \\
\hline RQ-1 & Typic Quartzipsamment/Haplic Arenosol/Neossolo Quartzarênico distrófico & Paraipabas & $\mathrm{CE}$ \\
\hline LA-1 & Typic Acrudox/Geric Ferralsol/Latossolo Amarelo acriférrico & Viçosa & MG \\
\hline LV-1 & Typic Hapludox/Rhodic Ferralsol/Latossolo Vermelho distroférrico & Três Lagoas & MS \\
\hline LV-2 & Typic Acrudox/Geric Ferralsol/Latossolo Vermelho acriférrico & Cuiabá & MT \\
\hline LA-2 & Typic Hapludox/Xantic Ferralsol/Latossolo Amarelo distrófico & Capitão Poço & PA \\
\hline PVA-1 & Typic Hapludult/Haplic Acrisol/Argissolo Vermelho-Amarelo distrófico & Capitão Poço & PA \\
\hline LA-3 & Typic Hapludox/Xantic Ferralsol/Latossolo Amarelo distrófico & Ipixuna & PA \\
\hline LA-4 & Typic Hapludox/Xantic Ferralsol/Latossolo Amarelo distrófico & Ipixuna & PA \\
\hline NV-1 & Typic Kandiudult/Rhodic Ferralsol/Nitossolo Vermelho distroférrico & Maringá & PR \\
\hline LA-5 & Xantic Hapludox/Haplic Acrisol/Latossolo Amarelo distrófico argissólico & Ariquemes & RO \\
\hline PVA-2 & Typic Hapludult/Haplic Acrisol/Argissolo Vermelho-Amarelo distrófico & Ariquemes & RO \\
\hline LA-6 & Xantic Eutrudox/Xantic Ferralsol/Latossolo Amarelo eutrófico argissólico & Not identified & SC \\
\hline PVA-3 & Typic Hapludult/Haplic Acrisol/Argissolo Vermelho-Amarelo distrófico & Capão Bonito & SP \\
\hline LV-3 & Typic Acrudox/Geric Ferralsol/Latossolo Vermelho acriférrico & Guatapará & SP \\
\hline LV-4 & Typic Hapludox/Rhodic Ferralsol/Latossolo Vermelho distrófico & Piracicaba & SP \\
\hline PV & Typic Hapludult/Haplic Acrisol/Argissolo Vermelho distrófico & Piracicaba & SP \\
\hline PVA-4 & Typic Hapludult/Haplic Acrisol/Argissolo Vermelho-Amarelo distrófico & Piracicaba & SP \\
\hline NV-2 & Typic Kandiudult/Rhodic Ferralsol/Nitossolo Vermelho distrófico & Piracicaba & SP \\
\hline RQ-2 & Typic Quartzipsamment/Haplic Arenosol/Neossolo Quartzarênico distrófico & São Pedro & SP \\
\hline LVA-1 & Typic Hapludox/Xantic Ferralsol/Latossolo Vermelho-Amarelo distrófico & Três Barras & SP \\
\hline CX-1 & Typic Eutrochrept/Eutric Cambisol/Cambissolo Háplico Ta eutrófico & Irecê & BA \\
\hline $\mathrm{CX}-2$ & Vertic Eutrochrept/Eutric Cambisol/Cambissolo Háplico Ta eutrófico vértico & Irecê & BA \\
\hline LA-7 & Typic Eutrustox/Xantic Ferralsol/Latossolo Amarelo eutrófico & Irecê & BA \\
\hline LVA-2 & Typic Eutrustox/Xantic Ferralsol/Latossolo Vermelho-Amarelo eutrófico & Irecê & $\mathrm{BA}$ \\
\hline SS & Typic Natraqualf/Gleyic Solonckak/Salino-Sódico & Souza & PB \\
\hline
\end{tabular}


Table 2 - Chemical properties of soil samples of $0-0.2 \mathrm{~m}$ layer.

\begin{tabular}{|c|c|c|c|c|c|c|c|c|c|}
\hline Soil & $\begin{array}{c}\text { Organic } \\
\text { mater }\end{array}$ & Resin P & $\mathrm{K}^{+}$ & $\mathrm{Ca}^{2+}$ & $\mathrm{Mg}^{2+}$ & ${ }^{(1)} \mathrm{Na}^{+}$ & $\begin{array}{c}\text { Sum of } \\
\text { bases }\end{array}$ & CEC & $\begin{array}{c}\text { Base } \\
\text { saturation }\end{array}$ \\
\hline & $\mathrm{g} \mathrm{dm}^{-3}$ & $\mathrm{mg} \mathrm{dm}{ }^{-3}$ & - & - & -- mmol & $1^{-3}-\cdots$ & $\ldots$ & . & $\%$ \\
\hline GX & 12.7 & 11.0 & 1.45 & 27.2 & 6.8 & 1.1 & 36.4 & 72.6 & 50.1 \\
\hline RQ-1 & 21.7 & 4.0 & 1.13 & 15.9 & 6.8 & 0.3 & 24.2 & 37.0 & 65.4 \\
\hline LA- 1 & 25.2 & 5.0 & 0.89 & 2.1 & 1.3 & 0.2 & 4.5 & 99.7 & 4.5 \\
\hline LV-1 & 22.2 & 4.9 & 2.84 & 26.4 & 14.6 & 0.3 & 44.1 & 65.4 & 67.4 \\
\hline LV-2 & 27.4 & 3.5 & 0.78 & 1.2 & 1.1 & 0.2 & 3.3 & 70.6 & 4.7 \\
\hline LA-2 & 22.9 & 5.0 & 0.71 & 4.8 & 2.2 & 0.5 & 8.4 & 59.2 & 14.2 \\
\hline PVA-1 & 25.0 & 3.3 & 0.74 & 8.1 & 2.5 & 0.8 & 12.1 & 52.7 & 23.1 \\
\hline LA-3 & 37.9 & 5.8 & 1.06 & 9.2 & 8.3 & 1.2 & 19.8 & 101.7 & 19.5 \\
\hline LA-4 & 32.6 & 3.9 & 1.92 & 21.2 & 6.0 & 0.5 & 29.7 & 58.3 & 50.9 \\
\hline NV-1 & 14.9 & 1.4 & 0.99 & 17.1 & 7.0 & 0.3 & 25.4 & 70.6 & 35.9 \\
\hline LA- 5 & 19.9 & 6.9 & 2.62 & 15.5 & 3.6 & 0.4 & 22.1 & 52.4 & 42.2 \\
\hline PVA-2 & 22.4 & 4.9 & 1.32 & 7.9 & 3.6 & 0.2 & 13.1 & 37.7 & 34.8 \\
\hline LA- 6 & 24.1 & 13.6 & 2.13 & 36.3 & 10.6 & 0.8 & 49.8 & 96.5 & 51.6 \\
\hline PVA-3 & 40.8 & 1.3 & 2.33 & 4.3 & 2.4 & 0.2 & 9.2 & 117.8 & 7.8 \\
\hline LV-3 & 30.1 & 4.3 & 1.07 & 13.4 & 8.7 & 0.2 & 23.3 & 64.7 & 36.0 \\
\hline LV-4 & 27.9 & 45.4 & 3.84 & 16.8 & 10.8 & 0.3 & 31.8 & 83.6 & 37.9 \\
\hline PV & 27.9 & 2.8 & 0.70 & 22.3 & 8.1 & 0.2 & 31.4 & 71.8 & 43.7 \\
\hline PVA-4 & 25.1 & 3.6 & 0.74 & 10.3 & 3.5 & 0.3 & 14.8 & 53.1 & 27.8 \\
\hline $\mathrm{NV}-2$ & 45.0 & 10.2 & 2.16 & 50.0 & 14.1 & 0.2 & 66.6 & 100.9 & 66.0 \\
\hline RQ-2 & 17.9 & 2.8 & 0.71 & 1.8 & 0.7 & 1.0 & 4.6 & 48.5 & 9.5 \\
\hline LVA-1 & 36.1 & 4.9 & 1.95 & 7.9 & 3.3 & 0.6 & 14.0 & 62.1 & 22.5 \\
\hline CX-1 & 24.0 & 46.5 & 2.47 & 139.8 & 22.5 & 0.2 & 165.1 & 186.8 & 88.4 \\
\hline${ }^{(2)} \mathrm{CX}-2$ & 32.5 & 5.5 & 1.33 & 412.0 & 20.5 & 1.2 & 435.2 & 445.1 & 97.8 \\
\hline LA-7 & 23.3 & 24.4 & 7.56 & 87.6 & 17.0 & 0.5 & 112.8 & 125.7 & 89.7 \\
\hline LVA-2 & 25.0 & 42.9 & 13.84 & 118.6 & 25.6 & 0.7 & 158.7 & 169.7 & 93.5 \\
\hline SS & 24.5 & 13.4 & 2.34 & 166.8 & 40.6 & 43.6 & 262.8 & 270.8 & 97.1 \\
\hline
\end{tabular}

${ }^{(1)}$ Sodium extracted with $0.05 \mathrm{~mol} \mathrm{~L}^{-1} \mathrm{HCl}+0.0125 \mathrm{~mol} \mathrm{~L}^{-1} \mathrm{H}_{2} \mathrm{SO}_{4}, 1: 5(\mathrm{v} / \mathrm{v})$ soil/solution ratio. Other chemical analyses as described in Raij et al. (1987; 2001). ${ }^{(2)}$ Soil sample containing free carbonate.

determined through the aluminon method, (Wolf, 1982). The total Al content was determined in ICP-AES, after $\mathrm{HClO}_{4}+\mathrm{HNO}_{3}+\mathrm{HF}$ digestion. The non-exchangeable acidity was determined by the difference between the total acidity and exchangeable acidity obtained by titrimetric method.

Results were submitted to descriptive statistics for estimations of mean, median, upper and lower quartiles, and correlation and regression analysis for selected variables.

\section{RESULTS AND DISCUSSION}

The $\mathrm{pH}$ values in $\mathrm{CaCl}_{2}$ (Table 3), varied from 3.78 to 7.86 , with 4.58 as the most frequent value, and $75 \%$ of values between 4.25 and 5.52 . According to the limits established by Raij et al. (1987) for soils of São Paulo State, Brazil, $31 \%$ of samples presented very high active acidity $\left(\mathrm{pH}_{\mathrm{CaCl} 2} \leq 4.3\right), 38 \%$ high (4.4 to 5.0$), 4 \%$ medium (5.1 to 5.5 ), $8 \%$ low (5.6 to 6.0 ), and $19 \%$ very low $(>6.0)$.
For soil samples with medium to very high acidity $(\mathrm{pH}<5.6)$, the sum of bases $(\mathrm{SB})$, the cation exchange capacity (CEC) and base saturation (V\%) (Table 2) varied from 3.3 to $66.7 \mathrm{mmol}_{\mathrm{c}} \mathrm{dm}^{-3}$, from 37.7 to 117.8 $\mathrm{mmol}_{\mathrm{c}} \mathrm{dm}^{-3}$ and from 4.5 to $66.0 \%$, respectively. There were positive correlations between the values of $\mathrm{P}$ (resin), $\mathrm{Ca}^{2+}, \mathrm{Mg}^{2+}, \mathrm{K}^{+}, \mathrm{SB}, \mathrm{CEC}$ and $\mathrm{V} \%$ and soil $\mathrm{pH}$ (Table 4), and a negative correlation between aluminum saturation ( $\mathrm{m} \%)$, showing the importance of soil reaction on soil fertility and the conditions for crop production. The chemical properties values (Tables 2 and 3) were similar to those obtained by Pavan (1983) and Nachtigal \& Vahl (1989) for soils in the same $\mathrm{pH}$ range.

The titratable exchangeable acidity $\left(\mathrm{Al}^{3+}+\mathrm{H}_{\text {tit }}^{+}\right)$ varied between 0 to $18 \mathrm{mmol}_{\mathrm{c}} \mathrm{dm}^{-3}$, and the exchangeable aluminum $\left(\mathrm{Al}^{3+}\right)$ between 0 to $15 \mathrm{mmol}_{\mathrm{c}} \mathrm{dm}^{-3}$ (Table 3). This demonstrated that the exchangeable acidity was constituted mostly of $\mathrm{Al}^{3+}$. In samples with $\mathrm{pH}$ lower than 5.6, the contribution of $\mathrm{H}_{\text {tit }}^{+}$was highly significant, representing $50 \%$ or more of titrated exchangeable acidity in $35 \%$ of all samples. 
Table 3 - Values of $\mathrm{pH}$ in $\mathrm{CaCl}_{2}$ (active acidity) and SMP solutions, titratable exchangeable acidity, exchangeable aluminum, titratable hydrogen, soluble aluminum (Wolf-Morgan), direct (ammonium acetate at $\mathrm{pH}$ 7) and indirect (SMP pH) total acidity, non-exchangeable acidity, total aluminum, and aluminum saturation, for characterization of acidity components of soils from Brazilian regions.

\begin{tabular}{|c|c|c|c|c|c|c|c|c|c|c|c|c|}
\hline \multirow{2}{*}{ Soil } & \multicolumn{2}{|c|}{$\mathrm{pH}$} & \multicolumn{3}{|c|}{ Titratable acidity } & \multirow{2}{*}{$\begin{array}{l}\text { Soluble Al } \\
\text { (WM) }\end{array}$} & \multirow{2}{*}{$\begin{array}{c}\text { Non-exchange } \\
\text { Al }\end{array}$} & \multicolumn{2}{|c|}{ Total acidity } & \multirow{2}{*}{$\begin{array}{l}\text { Non-exchange } \\
\text { acidity }\end{array}$} & \multirow{2}{*}{$\begin{array}{c}\text { Total } \\
\text { Al }\end{array}$} & \multirow{2}{*}{$\begin{array}{c}\mathrm{Al} \\
\text { saturation }\end{array}$} \\
\hline & $\left(\mathrm{CaCl}_{2}\right)$ & SMP & $\mathrm{Al}^{3+}+\mathrm{H}^{+}$ & $\mathrm{Al}^{3+}$ & $\mathrm{H}^{+}$ & & & $\mathrm{Ca}(\mathrm{Oac})_{2}$ & SMP pH & & & \\
\hline & & & & $-\cdots$ & 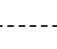 & . & $-\mathrm{mmol}_{\mathrm{c}} \mathrm{dm}^{-3}$ & - & 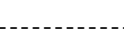 & & & \\
\hline GX & 4.56 & 6.05 & 5.8 & 3.7 & 2.1 & 6.9 & 3.19 & 37.1 & 36.2 & 30.4 & 52.8 & 9.2 \\
\hline RQ-1 & 5.52 & 7.48 & 0.1 & 0.0 & 0.1 & 0.2 & 0.23 & 12.6 & 12.8 & 12.7 & 13.5 & 0.0 \\
\hline LA- 1 & 3.82 & 5.19 & 17.5 & 13.4 & 4.1 & 14.3 & 0.86 & 91.9 & 95.2 & 77.7 & 79.0 & 75.0 \\
\hline LV-1 & 5.52 & 6.83 & 0.7 & 0.2 & 0.5 & 1.2 & 0.99 & 21.1 & 21.3 & 20.6 & 49.5 & 0.5 \\
\hline LV-2 & 4.10 & 5.50 & 9.4 & 6.9 & 2.5 & 10.3 & 3.33 & 66.2 & 67.3 & 57.8 & 98.3 & 67.9 \\
\hline LA-2 & 3.78 & 6.02 & 12.3 & 7.6 & 4.7 & 10.6 & 2.93 & 48.7 & 50.8 & 38.4 & 42.6 & 47.7 \\
\hline PVA-1 & 3.98 & 6.18 & 8.0 & 5.0 & 3.0 & 8.8 & 3.85 & 40.0 & 40.5 & 32.6 & 48.9 & 29.1 \\
\hline LA-3 & 3.91 & 5.36 & 13.4 & 9.1 & 4.3 & 8.0 & -1.05 & 80.4 & 81.9 & 68.6 & 90.0 & 31.5 \\
\hline LA-4 & 4.72 & 6.56 & 2.2 & 0.7 & 1.5 & 8.2 & 7.44 & 29.0 & 28.6 & 26.4 & 34.8 & 2.4 \\
\hline NV-1 & 4.64 & 6.02 & 5.3 & 3.7 & 1.6 & 9.3 & 5.60 & 44.6 & 45.2 & 40.0 & 101.8 & 12.7 \\
\hline LA-5 & 4.52 & 6.50 & 2.9 & 1.5 & 1.4 & 2.4 & 0.86 & 30.0 & 30.3 & 27.3 & 52.7 & 6.5 \\
\hline PVA-2 & 4.54 & 6.73 & 1.7 & 0.8 & 0.9 & 1.8 & 0.99 & 24.4 & 24.6 & 22.9 & 34.2 & 6.0 \\
\hline LA- 6 & 4.58 & 5.91 & 6.7 & 4.2 & 2.5 & 8.1 & 3.85 & 45.6 & 46.7 & 39.9 & 49.8 & 7.8 \\
\hline PVA-3 & 4.25 & 4.94 & 17.7 & 14.7 & 3.0 & 21.8 & 7.11 & 98.3 & 108.6 & 90.9 & 90.8 & 61.6 \\
\hline LV-3 & 4.63 & 6.02 & 0.6 & 0.3 & 0.3 & 7.1 & 6.79 & 40.9 & 41.4 & 40.8 & 105.3 & 1.2 \\
\hline LV-4 & 4.57 & 5.88 & 4.1 & 2.2 & 1.9 & 2.1 & -0.10 & 51.4 & 51.8 & 47.7 & 78.3 & 6.6 \\
\hline PV & 4.72 & 6.13 & 2.0 & 0.8 & 1.2 & 2.3 & 1.45 & 40.4 & 40.4 & 38.4 & 66.2 & 2.5 \\
\hline PVA-4 & 4.28 & 6.32 & 7.6 & 5.4 & 2.2 & 9.9 & 4.47 & 38.2 & 38.3 & 30.7 & 38.3 & 27.0 \\
\hline NV-2 & 5.28 & 6.30 & 0.3 & 0.1 & 0.2 & 1.7 & 1.59 & 33.0 & 34.3 & 34.0 & 66.3 & 0.2 \\
\hline RQ-2 & 3.96 & 6.33 & 11.1 & 8.4 & 2.7 & 17.4 & 9.01 & 41.6 & 43.9 & 32.9 & 13.5 & 64.6 \\
\hline LVA-1 & 4.43 & 6.10 & 7.5 & 5.0 & 2.5 & 16.8 & 11.73 & 47.8 & 48.1 & 40.6 & 26.7 & 26.6 \\
\hline CX-1 & 6.06 & 6.75 & 0.8 & 0.1 & 0.7 & 1.3 & 1.23 & 22.9 & 21.7 & 21.0 & 66.2 & 0.1 \\
\hline CX-2 & 7.58 & 7.52 & 0.0 & 0.0 & 0.0 & 1.9 & 1.91 & 11.2 & 9.8 & 9.8 & 59.1 & 0.0 \\
\hline LA-7 & 6.74 & 7.31 & 0.0 & 0.0 & 0.0 & 0.5 & 0.45 & 13.2 & 12.9 & 12.9 & 55.3 & 0.0 \\
\hline LVA- 2 & 7.29 & 7.42 & 0.0 & 0.0 & 0.0 & 0.8 & 0.77 & 11.9 & 11.0 & 11.0 & 58.8 & 0.0 \\
\hline SS & 7.86 & 7.77 & 0.2 & 0.0 & 0.2 & 1.2 & 1.25 & 8.6 & 7.9 & 7.8 & 61.5 & 0.0 \\
\hline
\end{tabular}

Aluminum $\left(\mathrm{Al}^{3+}\right)$ was the predominant exchangeable cation $(\mathrm{m} \%>30)$ in $23 \%$ of the analyzed soils, and in $32 \%$ of those with $\mathrm{pH}$ lower than 5.6. This result differs from that verified by Pavan (1983) in acid soils of Paraná, and explains that even in soil with high acidity, the $\mathrm{Al}^{3+}$ may not be present and $\mathrm{Al}^{3+}$ is a function of parent material and of soil mineralogy. The high $\mathrm{Ca}^{2+}$ and $\mathrm{Mg}^{2+}$ content (Table 2) and the negative correlation between these cations with $\mathrm{Al}^{3+}$ (Table 4) may indicate that a significant fraction of soluble $\mathrm{Al}$ could have been neutralized by the liming.

In acid mineral soils, the $\mathrm{H}_{\text {tit }}^{+}$present in the $\mathrm{KCl}$ soil extract is not derived from $\mathrm{Al}^{3+\text { tit }}$ displaced from exchange sites; it is rather the result of $\mathrm{pH}$ dependent hydrolysis reactions that involve the hydroxi- $\mathrm{Al}(\mathrm{OH})_{\mathrm{x}}$ forms, the organic matter, and the $\mathrm{Al}$ and Fe oxides (Kissel et al., 1971; Thomas \& Hargrove, 1984). Hiradate et al. (1998), using the nuclear magnetic resonance technique for the $\mathrm{Al}$ speciation of acid soil samples in $\mathrm{KCl}$ solution, verified that 92 to $96 \%$ of $\mathrm{Al}^{3+}$ were made of electrically symmetric octahedral $\mathrm{Al}$ (monomer and dymer of hydroxi-Al) and of organically complexed $\mathrm{Al}$, respectively. However, the behavior of hydrogen bound to exchange complex depends on the nature of soil colloids. When associated to constant negative charge of 2:1 clay minerals, with planar surface, the $\mathrm{H}^{+}$ion is retained by electrostatic forces, i.e., as exchangeable cation; when associated to variable negative charge of organic matter, kaolinite, allophane and iron and aluminum oxides, the hydrogen is retained by covalent bound, i.e., non-exchangeable cation (Kinjo, 1983). Therefore, in acid mineral soils, the $\mathrm{H}_{\text {tit }}^{+}$present in non-buffered $\mathrm{KCl}$ soil solution extract does not represent the soil exchangeable acidity, but the low stability hydroxi-Al forms, except in soils with high organic matter content (Oates \& Kamprath, 1983; Raij et al., 1987; 2001). 
Table 4 - Correlation coefficient between attributes related to acidity and fertility of soils from Brazilian regions.

\begin{tabular}{|c|c|c|c|c|c|c|c|c|}
\hline \multirow{2}{*}{$\begin{array}{l}\text { Soil } \\
\text { properties }\end{array}$} & \multicolumn{2}{|c|}{ Titratable } & \multirow{2}{*}{ Soluble Al } & \multirow{2}{*}{$\begin{array}{c}\text { Non-exchange } \\
\text { Al }\end{array}$} & \multirow{2}{*}{$\begin{array}{c}\text { Non-exchenge } \\
\text { acidity }\end{array}$} & \multirow{2}{*}{$\begin{array}{c}\text { Total } \\
\text { acidity at } \\
\text { pH } 7\end{array}$} & \multirow{2}{*}{ Total Al } & \multirow{2}{*}{$\begin{array}{c}\mathrm{pH} \\
(\mathrm{CaCl})\end{array}$} \\
\hline & $\mathrm{Al}^{3+}$ & $\mathrm{H}^{+}$ & & & & & & \\
\hline \multicolumn{9}{|c|}{ All soils $(N=26)$} \\
\hline $\mathrm{pH}\left(\mathrm{CaCl}_{2}\right)$ & $-0.637 * * *$ & $-0.775 * * *$ & $-0.633 * * *$ & -0.345 & $-0.691 * * *$ & $-0.709 * * *$ & -0.053 & -- \\
\hline $\begin{array}{l}\text { Organic } \\
\text { mater }\end{array}$ & 0.164 & 0.047 & 0.184 & 0.128 & $0.388 *$ & 0.344 & 0.253 & -0.005 \\
\hline $\mathrm{P}$ (resin) & -0.349 & -0.315 & $-0.453 *$ & $-0.389 *$ & -0.269 & -0.294 & 0.094 & $0.449 *$ \\
\hline $\mathrm{Ca}^{2+}$ & $-0.401 *$ & $-0.495 *$ & $-0.409 *$ & -0.236 & $-0.491 *$ & $-0.492 *$ & 0.015 & $0.801 * * *$ \\
\hline $\mathrm{Mg}^{2+}$ & $-0.562 * *$ & $-0.629 * * *$ & $-0.606 * *$ & $-0.391 *$ & $-0.562 * *$ & $-0.584 * *$ & 0.094 & $0.907 * * *$ \\
\hline $\mathrm{K}^{+}$ & -0.310 & $-0.409 *$ & -0.355 & -0.257 & -0.329 & -0.341 & 0.001 & $0.560 * *$ \\
\hline SB & $-0.435^{*}$ & $-0.533 * *$ & $-0.449 *$ & -0.265 & $-0.527 * *$ & $-0.529 * *$ & 0.023 & $0.864 * * *$ \\
\hline CEC & -0.224 & -0.368 & -0.281 & -0.231 & -0.302 & -0.303 & 0.163 & $0.764 * * *$ \\
\hline $\mathrm{V} \%$ & $-0.788 * * *$ & $-0.821 * * *$ & $-0.779 * * *$ & $-0.418 *$ & $-0.782 * * *$ & $-0.811 * * *$ & -0.137 & $0.932 * * *$ \\
\hline $\mathrm{m} \%$ & $0.917 * * *$ & $0.784 * * *$ & $0.820 * * *$ & 0.322 & $0.727 * * *$ & $0.785 * * *$ & 0.131 & $-0.607 * *$ \\
\hline \multicolumn{9}{|c|}{ Soil with $\mathrm{pH}\left(\mathrm{CaCl}_{2}\right)<5.6(\mathrm{~N}=21)$} \\
\hline $\mathrm{pH}\left(\mathrm{CaCl}_{2}\right)$ & $-0.752 * * *$ & $-0.879 * * *$ & $-0.657 * * *$ & -0.197 & $-0.565 * *$ & $-0.614 * * *$ & -0.178 & -- \\
\hline $\begin{array}{l}\text { Organic } \\
\text { mater }\end{array}$ & 0.165 & 0.036 & 0.183 & 0.111 & $0.458 *$ & 0.401 & 0.262 & 0.028 \\
\hline$P($ resin) & -0.189 & -0.049 & -0.319 & -0.323 & 0.021 & -0.020 & 0.110 & 0.102 \\
\hline $\mathrm{Ca}^{2+}$ & $-0.592 * *$ & $-0.541 *$ & $-0.558 * *$ & -0.226 & -0.381 & $-0.444 *$ & -0.027 & $0.693 * * *$ \\
\hline $\mathrm{Mg}^{2+}$ & $-0.591 * *$ & $-0.546^{*}$ & $-0.634 * * *$ & -0.362 & -0.270 & -0.356 & 0.168 & $0.731 * * *$ \\
\hline $\mathrm{K}^{+}$ & -0.247 & -0.295 & -0.256 & -0.135 & -0.011 & -0.070 & 0.038 & $0.437 *$ \\
\hline SB & $-0.607 * *$ & $-0.554 * *$ & $-0.590 * *$ & -0.265 & -0.360 & -0.431 & 0.015 & $0.725 * * *$ \\
\hline CEC & $0.512 *$ & 0.341 & 0.308 & -0.114 & $0.793 * * *$ & $0.751 * * *$ & $0.626^{* *}$ & -0.152 \\
\hline $\mathrm{V} \%$ & $-0.828 * * *$ & $-0.769 * * *$ & $-0.771 * * *$ & -0.299 & $-0.682 * * *$ & $-0.743 * * *$ & -0.258 & $0.908 * * *$ \\
\hline $\mathrm{m} \%$ & $0.903 * * *$ & $0.747 * * *$ & $0.787 * * *$ & 0.232 & $0.676 * * *$ & $0.750 * * *$ & 0.151 & $-0.765 * * *$ \\
\hline
\end{tabular}

*significant $P<0.05$. ** significant $P<0.01$.***significant $P<0.001$

The concentration of low stability hydroxi-Al forms in soil samples from different regions of Brazil $\left(\mathrm{H}_{\text {tit }}^{+}\right.$contained in non-buffered $\mathrm{KCl}$ solution) varied from 0 to $4.7 \mathrm{mmol}_{\mathrm{c}} \mathrm{dm}^{-3}$ (Table 3 ) and was dependent on $\mathrm{Al}^{3+}$ content (Figure 1) and of sample pH (Table 4). In acid soils, there are predominance of $\mathrm{Al}^{3+}$ over the $\mathrm{Al}(\mathrm{OH})^{2+}$ and $\mathrm{Al}(\mathrm{OH})_{2}^{+}$, however with increasing $\mathrm{pH}$, there gradually occurs the increment of $\mathrm{OH} / \mathrm{Al}$ relation and of polymerization of hydroxi-Al forms. The formed polymers, of variable size and charges, neutralize negative charges but are not displaced in non-buffered saline solutions (Thomas \& Hargrove, 1984). Therefore, in acid mineral soil containing 1:1 clay minerals and $\mathrm{Al}, \mathrm{Fe}$ oxides, the lower the hydroxi-Al forms content, the higher is the proportion of their hydrolysable forms, resulting from lower polymerization (stability) of these Al forms, which produces $\mathrm{H}^{+}$in $\mathrm{KCl}$ extract (Kissel et al., 1971).

The soluble Al content obtained by Wolf-Morgan extractant (WM-Al) varied from 0.2 to $21.8 \mathrm{mmol}_{\mathrm{c}} \mathrm{dm}^{-3}$ (Table 3), with most frequent value of $7.0 \mathrm{mmol}_{\mathrm{c}}^{\mathrm{c}} \mathrm{dm}^{-3}$ $\left(8.2 \mathrm{mmol}_{\mathrm{c}} \mathrm{dm}^{-3}\right.$ in samples with $\left.\mathrm{pH}<5.6\right)$ and were superior or near the $\mathrm{Al}^{3+}$ content in $\mathrm{KCl}$ neutral solution,

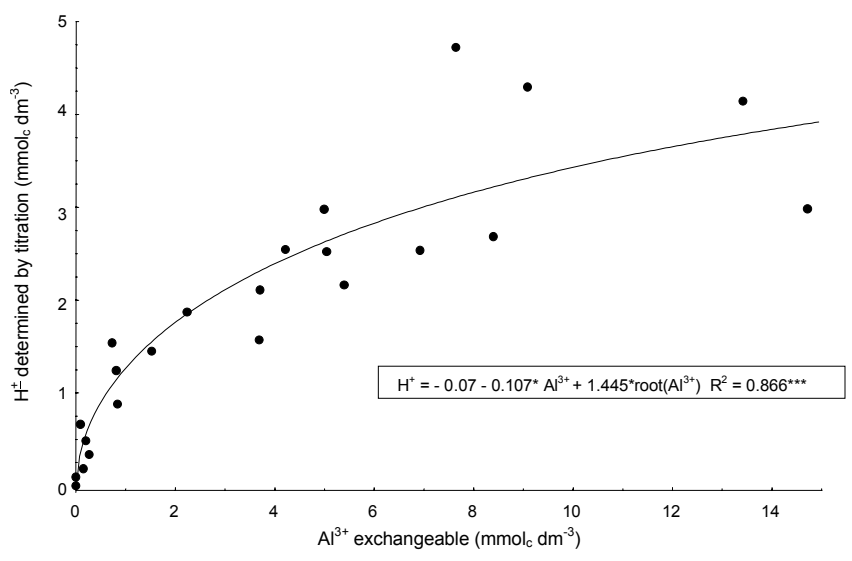

Figure 1 - Relation between the exchangeable aluminum $\left(\mathrm{Al}^{3+}\right)$ and the so-called exchangeable hydrogen $\left(\mathrm{H}^{+}{ }_{\text {tit }}\right)$ determined by titration, in $1 \mathrm{~mol} \mathrm{~L}^{-1} \mathrm{KCl}$ extract, for soil samples from Brazilian regions. In acid mineral soil, this $\mathrm{H}^{+}{ }_{\text {tit }}$ may indeed represent low stability hydroxi-Al.

except in LA-3 sample. Similar values of Al extracted with $1 \mathrm{~mol} \mathrm{~L}^{-1} \mathrm{NH}_{4} \mathrm{AO}_{\mathrm{c}}(\mathrm{pH} 4.8$ ), to obtain the exchangeable + non-exchangeable Al, was reported by Pavan (1983) in soil samples from Paraná with the same range 
of $\mathrm{Al}^{3+}$ of this work. This indicates that the Wolf-Morgan solution extracts exchangeable $\mathrm{Al}$ and non-exchangeable $\mathrm{Al}$ as well, which may be toxic to plants (Noble et al., 1988; Hiradate et al., 1998). Therefore, the Al obtained by difference between WM-Al and $\mathrm{Al}^{3+}$ constitute the non-exchangeable Al (Table 3), and those values varied from 0 to $11.7 \mathrm{mmol}_{\mathrm{c}} \mathrm{dm}^{-3}$. Similar results were observed by Pavan (1983) in soil samples with the same variation in $\mathrm{Al}^{3+}$.

The Al contents of exchangeable and of low polymerization degree hydroxi forms diminish rapidly with the sample $\mathrm{pH}$ increment up to 5.5 value; through the non-exchangeable form increased up to $\mathrm{pH} 4.5$, decreased thereafter up to $\mathrm{pH} 5.5$, and increased slowly with the $\mathrm{pH}$ of 7.0 to 7.5 (Figure 2), according to the stage of polymerization of hydroxi-Al forms which are functions of pH and of organic matter (McLean, 1965; Kissel et al., 1971; Pavan, 1983; Thomas \& Hargrove, 1984).

The determined total acidity was 8.6 to 91.9 $\mathrm{mmol}_{\mathrm{c}} \mathrm{dm}^{-3}$ and those obtained by SMP $\mathrm{pH}, 7.9$ to 95.2 $\mathrm{mmol}_{\mathrm{c}}^{\mathrm{c}} \mathrm{dm}^{-3}$, with most frequent values of 39.1 to 39.4 $\mathrm{mmol}_{\mathrm{c}}^{\mathrm{c}} \mathrm{dm}^{-3}$, respectively. The indirect determination of total acidity (Raij et al., 1987) is based on SMP pH (buffered at $\mathrm{pH}$ 7.5) variations in consequence of $\mathrm{H}^{+}, \mathrm{Al}^{3+}$ and $\mathrm{OH}^{-}$ions released by soil colloids and organic matter, which allows to establish the relationship between the $\mathrm{pH}$ of SMP solution and the $\mathrm{H}^{+}+\mathrm{Al}^{3+}$ content in the soil sample.

The analysis of the relationship between exchangeable aluminum with total acidity and base saturation of the soils (Figure 3 ) revealed that a small increase in $\mathrm{Al}^{3+}$ content $\left(0\right.$ to $\left.0.2 \mathrm{mmol}_{\mathrm{c}} \mathrm{dm}^{-3}\right)$ results in a quick evolution of total acidity ( 8.6 to $21.1 \mathrm{mmol}_{\mathrm{c}} \mathrm{dm}^{-3}$ ). This generated acidity, for soils with $\mathrm{pH} \geq 5.6$, is exclusively attributed to $\mathrm{H}^{+}$ions (Table 3). Thereafter, when $\mathrm{Al}^{3+}>$ $0.2 \mathrm{mmol}_{\mathrm{c}} \mathrm{dm}^{-3}$, the total acidity increased $5.1 \mathrm{mmol}_{\mathrm{c}} \mathrm{dm}^{-3}$, on average, for each released $\mathrm{mmol}_{\mathrm{c}} \mathrm{dm}^{-3}$ of $\mathrm{Al}^{3+}$. Simultaneously, the base saturation reduced drastically with increasing $\mathrm{Al}^{3+}$ content from 0 to $4 \mathrm{mmol}_{\mathrm{c}} \mathrm{dm}^{-3}$; above this boundary value, the effect of increasing $\mathrm{Al}^{3+}$ was much smaller in reducing soil V\%.

There was a very narrow relationship between the total acidity obtained directly and indirectly (Figure 4a) and the obtained exponential relationship between SMP $\mathrm{pH}$ and the determined total acidity (Figure 4b) was much similar to that used by laboratories of soil analyses, mainly in the State of São Paulo (Raij et al., 1987; 2001). This indicates that the SMP $\mathrm{pH}$ method can be used for the evaluation of total acidity of soils practically from all Brazilian regions. Recently, Nascimento (2000) and Silva et al. (2000) established second degree equations for the calculation of $\mathrm{H}^{+}+\mathrm{Al}^{3+}$ by SMP $\mathrm{pH}$ method in soils of Pernambuco and of Semi-Arido of Brazilian Northeast, respectively.
Although, unlike Pavan's (1983) paper, significant correlations have not been verified among the variables associated to the soil acidity and the organic matter content (Table 4), except for non-exchangeable acidity, it is known that in acid soils the organic matter can play an important role in $\mathrm{Al}^{3+}$ complexation (McLean, 1965; Pavan, 1983; Oates \& Kamprath, 1984; Hiradate et al., 1998), reducing the toxic effect of aluminum to plants. This fact may have an important role in agricultural systems with management of crop residues or of organic fertilizers, for which the liming would be reduced without affecting productivity, increasing the cost/benefit relationship. The relationship with organic matter explains also the $\mathrm{Al}^{3+}$ content reduction along the acid soil profile (McLean, 1965).

There were correlations $(P<0.001)$ between the soil Al saturation $(\mathrm{m} \%)$ and other acidity associated variables (Table 4), except for total Al. The total Al only correlated with the CEC of soil with $\mathrm{pH}$ bellow 5.6, evidencing different mineralogy among the studied soil samples.
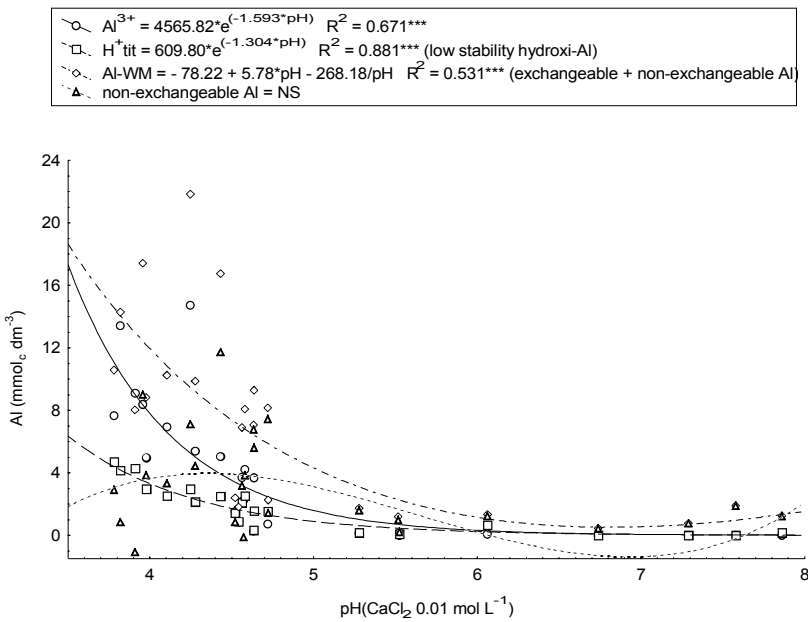

Figure 2 - Relationships between $\mathrm{pH}$, in $0.01 \mathrm{~mol} \mathrm{~L}^{-1} \mathrm{CaCl}_{2}$, and exchangeable aluminum $\left(\mathrm{Al}^{3+}\right)$, low stability hydroxiAl $\left(\mathrm{H}^{+}{ }_{\mathrm{tit}}\right)$, exchangeable plus non-exchangeable aluminum (Wolf-Morgan Al), and non-exchangeable aluminum for soil samples from Brazilian regions.

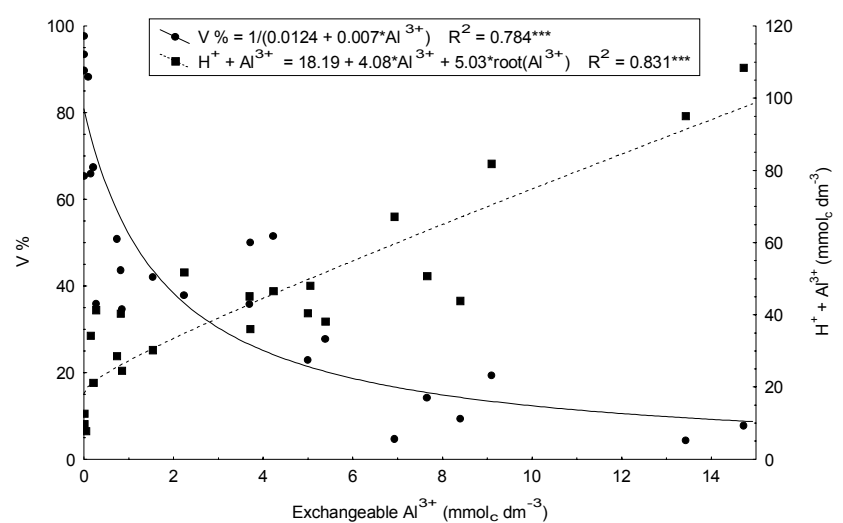

Figure 3 - Relationships between the exchangeable aluminum $\left(\mathrm{Al}^{3+}\right)$ and base saturation $(\mathrm{V} \%)$ and total acidity at $\mathrm{pH} 7$ $\left(\mathrm{H}^{+}+\mathrm{Al}^{3+}\right)$ for soil samples from Brazilian regions. 

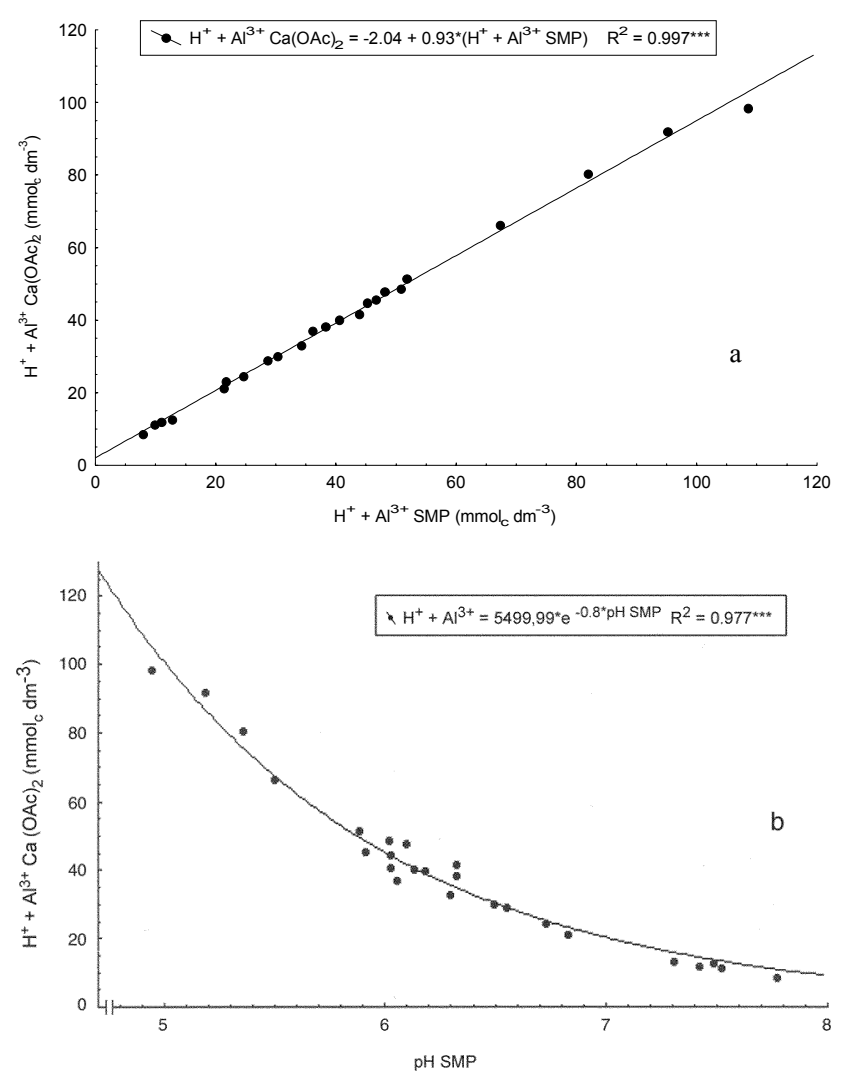

Figure 4 - Relationships between the total acidity $\left(\mathrm{H}^{+}+\mathrm{Al}^{3+}\right)$ determined by SMP buffer $\mathrm{pH}$ and by ammonium acetate at $\mathrm{pH} 7$ (a), and between the $\mathrm{pH}$ of SMP buffer solution and the total acidity with ammonium acetate at $\mathrm{pH} 7$ (b) for soil samples from Brazilian regions.

\section{REFERENCES}

EMBRAPA. Centro Nacional de Pesquisa de Solos. Sistema brasileiro de classificação de solos. Brasília: Embrapa Produção de Informação; Rio de Janeiro: Embrapa Solos, 1999. 412p.

FAO. Soil map of the world. Revised legend with corrections. Rome: FAO; UNESCO; Wageningen: ISRIC, 1994. 140p. (World Resources Report, 60)

HIRADATE, S.; TANIGUCHI, S.; SAKURAI, K. Aluminum speciation in aluminum-silica solutions and potassium chloride extracts of acidic soils. Soil Science Society of America Journal, v.62, p.630-636, 1998.
KINJO, T. Conceitos de acidez de solos. In: RAIJ. B.van; BATAGLIA, O.C.; SILVA, N.M. (Coord.) Acidez e calagem no Brasil. Campinas: SBCS, 1983. p.23-31.

KISSEL, D.E.; GENTZSCH, E.P.; THOMAS, G.W. Hydrolysis of nonexchangeable acidity in soils during salt extractions of exchangeable acidity. Soil Science, v.111, p.293-297, 1971.

McLEAN, E.O. Aluminum. In: BLACK, C.A. (Ed.) Methods of soil analysis: Part 2. Chemical methods. Madison: ASA, 1965. p.978-998.

NACHTIGALL, G.R.; VAHL, L.C. Parâmetros relacionados à acidez em solos da região sul do Rio Grande do Sul. Revista Brasileira de Ciência do Solo, v.13, p.139-143, 1989.

NASCIMENTO, C.W.A. Acidez potencial estimada pelo pH SMP em solos do Estado de Pernambuco. Revista Brasileira de Ciência do Solo, v.24, p.679-682, 2000.

NOBLE, A.D.; SUMMER, M.E.; ALVA, A.K. Suitability of the aluminon technique for measuring phytotoxic aluminum in solution with varying sulfate concentrations. Communications in Soil Science and Plant Analysis, v.19, p.1495-1508, 1988.

OATES. K.M.; KAMPRATH, E.J. Soil acidity and liming: I. Effect of the extracting solution cation and $\mathrm{pH}$ on the removal of aluminum from acid soils. Soil Science Society of America Journal, v.47, p.686-689, 1983.

PAVAN, M.A. Alumínio em solos ácidos do Paraná: relação entre o alumínio não-trocável, trocável e solúvel, com o $\mathrm{pH}, \mathrm{CTC}$, porcentagem de saturação de $\mathrm{Al}$ e matéria orgânica. Revista Brasileira de Ciência do Solo, v.7, p.39-46, 1983.

RAIJ, B. van; ANDRADE, J.C.; CANTARELLA, H.; QUAGGIO, J.A. Análise química para avaliação da fertilidade de solos tropicais. Campinas: Instituto Agronômico, 2001. 285p.

RAIJ, B. van; QUAGGIO, J.A.; CANTARELLA, H.; FERREIRA, M.E.; LOPES, A.S.; BATAGLIA, O.C. Análise química do solo para fins de fertilidade. Campinas: Fundação Cargill, 1987. 170p.

SILVA, C.A.; AVELLAR, M.L.; BERNARDI, A.C.C. Estimativa da acidez potencial pelo $\mathrm{pH}$ SMP em solos do Semi-Árido do Nordeste Brasileiro. Revista Brasileira de Ciência do Solo, v.24, p.689-692, 2000.

SOIL SURVEY STAFF. Soil taxonomy: a basic system of soil classification form making and interpreting soil surveys. Washington: USDA, 1999. 869p. (Handbook, 436)

THOMAS, G.W.; HARGROVE, W.L. The chemistry of soil acidity. In ADAMS, F. (Ed.) Soil acidity and liming. Madison: ASA, CSSA, SSSA, 1984. cap.1, p.3-56.

WOLF, B. An improved universal extracting solution and its use for diagnosing soil fertility. Communications in Soil Science and Plant Analysis, v.13, p.1005-1033, 1982.

Received August 19, 2002 